\title{
Analisis Penanaman Modal Asing di Indonesia Tahun 2007-2016: Pendekatan Model Gravitasi
}

\author{
Lisa Dewi Afrilita ${ }^{1}$ dan Dyah Titis Kusuma Wardani ${ }^{1}$
}

\begin{abstract}
Abstrak: Penelitian ini, bertujuan untuk melihat hubungan penanaman modal asing dengan ukuran ekonomi suatu negara dan jarak menggunakan pendekatan model gravitasi. Adapun variabel yang digunakan dalam penelitian ini, yakni Produk Domestik Bruto (PDB) per kapita Indonesia, Produk Domestik Bruto (PDB) per kapita negara investor, jarak negara Indonesia dengan negara investor, pendidikan terakhir tenaga kerja di Indonesia, indeks stabilitas politik Indonesia dan keterbukaan ekonomi Indonesia dengan mencakup lima negara investor terbesar di Indonesia, dari tahun 2007 - 2016. Hasil penelitian ini PDB per kapita Indonesia, PDB per kapita negara investor, jarak, dan keterbukaan ekonomi Indonesia berpengaruh terhadap penanaman modal asing Indonesia sedangkan pendidikan terakhir tenaga kerja Indonesia dan Indeks Stabilitas Politik Indonesia tidak berpengaruh. Sehingga dapat disimpulkan bahwa model gravitasi sudah relevan secara empiris untuk diterapkan pada kasus penanaman modal asing Indonesia.
\end{abstract}

THIS ARTICLE IS AVALILABLE IN:

http://journal.umy.ac.id/index.php/jerss

DOI: $10.18196 /$ jerss.030106

Kata kunci: Penanaman Modal Asing; Model Gravitasi; PDB per kapita; Indonesia.

SITASI:

Afrilita, L. D., \& Wardani, D. T. K. (2019). Analisis Penanaman Modal Asing di Indonesia Tahun 2007-

2016: Pendekatan Model Gravitasi. Journal of Economics Research and Social Sciences, 3(1), 48-55.

\section{Pendahuluan}

Investasi, khususnya Penanaman Modal Asing (PMA) merupakan salah satu instrumen penting dalam pembangunan negara mengingat Indonesia merupakan negara dengan sumber daya alam melimpah. Oleh karena itu, Pemerintah Indonesia dalam Undang - Undang No 25 tahun 2007 berupaya mempercepat perekonomian nasional melalui peningkatan penanaman modal guna mengelola potensi sumber daya yang ada dengan modal dari dalam negeri dan luar negeri. Menurut Sarwedi (2001), Penanaman Modal Asing jauh lebih penting dalam menjamin pembangunan dibandingkan dengan aliran bantuan dana. Pernyataan tersebut didasari pada teori tabungan dan investasi dalam model HarrodDomar mengenai pembangunan ekonomi di mana pertumbuhan ekonomi ditentukan oleh tingginya tabungan dan investasi. Melalui penanaman modal, perusahaan membuka lapangan pekerjaan yang mampu menyerap tenaga kerja lokal dengan maksimal. Perusahaan asing yang beroperasi di Indonesia kemudian mampu mengedukasi pekerja mengenai kualitas produk, teknologi produksi, dan etos kerja yang baik. Jadi, investasi tidak hanya dilakukan untuk kepentingan ekonomi, tetapi juga membangun investasi intelektual bagi tenaga kerja. Hal ini sesuai dengan teori Borensztein, De Gregorio, dan Lee (1998) bahwa PMA dapat memberikan keuntungan dalam pertumbuhan ekonomi melalui adopsi teknologi baru dan peningkatan sumber daya manusia. 


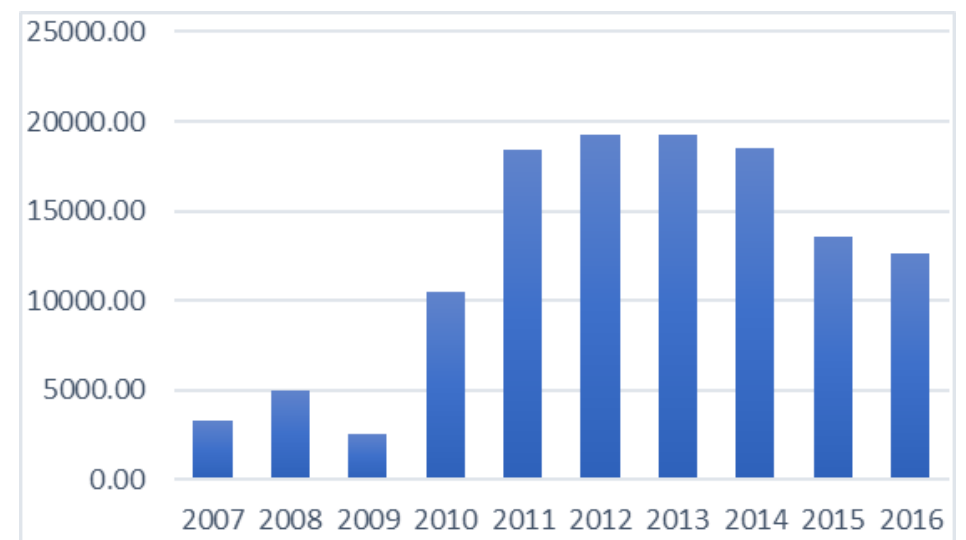

Gambar 1 Perkembangan Penanaman Modal Asing di Indonesia

Tahun 2007-2016 (Juta USD)

Sumber : World Bank (2018)

Sebagai salah satu negara berkembang di Asia Tenggara, penanaman modal asing Indonesia cenderung mengalami fluktuasi dari tahun 2007 hingga 2016. Pada tahun 2007, nilainya sebesar USD 3.254 juta, lalu mengalami peningkatan tahun 2008. Selanjutnya, penurunan drastis terjadi pada tahun 2009, yaitu sejumlah USD 2.553 juta. Hal ini terjadi akibat penularan krisis global yang terus menurun mencapai 4,5\%. Angka tersebut kemudian kembali stabil dari tahun 2010 dan terus meningkat hingga tahun 2014, meskipun sempat mengalami penurunan pada tahun 2015 dan 2016.

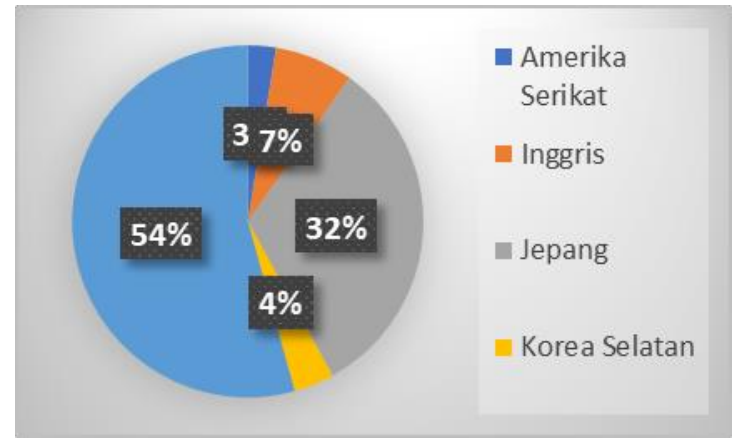

Gambar 2 Penanaman Modal Asing di Indonesia menurut Lima Negara Investor Terbesar Tahun 2007 - 2016

Sumber : World Bank (2018)

Berdasarkan gambar 2, terdapat lima negara dengan penanaman modal asing terbesar di Indonesia, yakni Singapura sebesar 54\%, lalu disusul oleh Jepang dengan 31\%, Inggris 7\%, Korea Selatan 4\%, dan Amerika Serikat 3\%. Singapura menjadi negara investor terbesar di Indonesia mengingat kedekatan jarak geografis kedua negara beserta kerja sama negara tersebut dengan Jakarta dan Batam dalam perdagangan bebas pajak.

Mengingat investasi terbesar didapatkan dari negara Singapura, hal ini mungkin berkaitan dengan model gravitasi perdagangan yang menyajikan sebuah analisis mengenai arus perdagangan internasional yang ditentukan oleh jarak antar negara dan 


\author{
Afrilita \& Wardani \\ Analisis Penanaman Modal Asing di Indonesia Tahun 2007-2016: Pendekatan Model Gravitasi
}

interaksi antar negara melalui ukuran ekonominya. Model ini berasal dari hukum gravitasi Newton yang memperhitungkan ukuran fisik antara dua benda, di mana ketika semakin jauh jarak kedua benda, maka gaya gravitasinya akan semakin kecil. Sementara itu, ukuran fisik suatu benda diartikan sebagai massa, yakni semakin besar massa suatu benda, semakin besar pula gaya hantamnya. Model ini telah menjadi kuat secara empiris oleh analisis ekonometrika.

Tulisan ini membahas bagaimana penanaman modal asing dipengaruhi oleh Produk Domestik Bruto (PDB) per kapita yang menunjukan ukuran negara investor dan jarak antara Indonesia dengan negara investor yang merupakan variabel inti dalam model gravitasi. Selain itu, penulis juga menambahkan beberapa variabel karakteristik negara, seperti pendidikan terakhir tenaga kerja Indonesia, derajat keterbukaan ekonomi Indonesia, dan stabilitas politik Indonesia. Dengan adanya hal tersebut, penulis ingin melihat seberapa relevan model gravitasi dapat digunakan untuk menjelaskan penanaman modal asing yang diperoleh negara tujuan dalam hal ini Indonesia.

\title{
Tinjauan Pustaka
}

Broadman dan Recanatini (2004) dalam penelitiannya menggunakan variabel dependen berupa PMA di negara Rusia. Untuk variabel penjelasnya, mereka menggunakan berbagai indikator pembangunan daerah dengan ciri pembangunan ekonomi, infrastruktur, kebijakan tenaga kerja, pengembangan masyarakat dan kelembagaan, georafis, dan stabilitas sosial. Penelitiannya menggunakan data panel tahun 1995-2000 dan mendapati bahwa ukuran pasar, pengembangan infrastruktur, kebijakan lingkungan, dan efek aglomerasi menjelaskan variasi aliran PMA yang diamati di seluruh Rusia.

Svetlana dan Mikael (2006) menjelaskan bahwa terdapat beberapa faktor yang memiliki pengaruh besar terhadap investor asing dalam membuat keputusan untuk berinvestasi di suatu negara. Yang pertama, ketersediaan sumberdaya alam. Kedua, tingkat aglomerasi suatu negara. Ketiga, potensi pasar suatu daerah dan keempat, keuntungan yang bisa didapatkan. Selain itu, menurut Buch, Kokta, dan Piazolo (2003) dalam penelitiannya di Eropa Selatan, penentu PMA negara tuan rumah adalah pangsa pasar serta insentif jarak antar negara. Selain itu, terdapat pengaruh signifikan positif dari PDB per kapita.

Shatz dan Venables (2000) menekankan pentingnya politik, keterbukaan perdagangan dan susunan kelembanggaan sebagai penentu adanya investasi asing. Selain itu, perbedaan tingkat pendidikan, kualitas manusia dan kepastian hukum tidak kalah penting. Frenkel, Funke, dan Stadtmann (2004) menemukan bahwa jarak dan ukuran suatu pasar, memainkan peran penting untuk aliran PMA, begitu pun dengan karakteristik politik dan pertumbuhan ekonomi di negara tuan rumah. 


\section{Metode Penelitian}

Penelitian ini mencakup lima negara dengan investasi terbesar di Indonesia selama tahun 2007 hingga 2016, yakni: Singapura, Jepang, Inggris, Korea Selatan, dan Amerika Serikat. Dalam penelitian ini, penulis menggunakan data sekunder. Data sekunder adalah data yang diambil dari berbagai sumber yang telah ada sehingga penulis hanya menggunakan data tersebut. Data sekunder ini diperoleh dari beberapa data yang kredibel, seperti Bank Indonesia, World Bank, dan distancefrom.net untuk data berupa jumlah PDB per kapita negara Indonesia dan negara investor, keterbukaan ekonomi negara tuan rumah, stabilitas politik negara tuan rumah dan investor, tingkat pendidikan negara tuan rumah, serta jarak antar negara.

Data dalam penelitian ini didapatkan dari berbagai basis data dan laporan statistik terpercaya, yakni melalui situs resmi Bank Indonesia, World Bank, dan distancefromto.net. Dalam penelitian ini, penulis menggunakan teknik dokumentasi, yang mengambil data dan informasi terkait dengan meninjau kembali laporan-laporan tertulis berupa angka dan keterangan. Teknik dokumentasi dalam penelitian ini digunakan untuk mencari data jumlah PDB per kapita yang di peroleh di Negara Indonesia, PDB per kapita negara investor, jarak antara Indonesia dengan negara investor, tingkat pendidikan negara Indonesia, indeks stabilitas politik Negara Indonesia, serta keterbukaan ekonomi Negara Indonesia terhadap dunia.

Data panel merupakan gabungan antara data silang (cross section) dan runtut waktu (time series). Ada beberapa keuntungan dalam penggunaan data panel. Menurut Widarjono (2009), beberapa keuntungannya meliputi jumlah data yang lebih banyak sehingga menghasilkan derajat kebebasan (degree of freedom) yang lebih besar serta dapat mengatasi masalah yang timbul akibat masalah penghilangan variabel (ommited variabel).

Ada pun, model regresi panel dalam penelitian ini sebagai berikut:

$$
\log Y_{i t}=a+b_{1} \log X_{1 i t}+b_{2} \log X_{2 i t}+b_{3} \log X_{3 i t}+b_{4} X_{4 i t}+b_{5} X_{5 i t}+b_{6} X_{7 i t}+e_{i}
$$

\section{Keterangan:}

Y : Penanaman Modal Asing (Juta USD)

$\alpha$ : Konstanta

$x_{1}:$ Jarak (Mil)

$x_{2}:$ :PDB per kapita negara tuan rumah (Juta USD)

$x_{3}$ : PDB per kapita negara investor (Juta USD)

$\mathrm{x}_{4}:$ tingkat pendidikan (\%)

$\mathrm{x}_{5}:$ stabilitas politik negara tuan rumah (poin)

$x 6$ : trade openness negara tuan rumah (\%)

e : Error term

$\mathrm{t}$ : Waktu

i : Negara 


\section{Hasil dan Pembahasan}

Tabel 1 Uji Multikoliniearitas

\begin{tabular}{lcc}
\hline & Variabel & VIF \\
\hline Log GDP per kapita Ind & 4,77 \\
\hline Log GDP per kapita inv & 3,12 \\
\hline Log Jarak & 3,11 \\
\hline Politik Indonesia & 3,01 \\
\hline Keterbukaan Ekonomi & 2.41 \\
PPTK & 1.47 \\
\hline Mean VIF & 2,98 \\
\hline
\end{tabular}

Sumber: Data diolah

Berdasarkan hasil Uji Multikolinearitas tabel 1, tidak terdapat masalah kolinearitas dalam penelitian, mengingat nilai Mean VIF dan nilai VIF masing-masing variabel kurang dari 5.

Tabel 2 Uji Heteroskedastisitas

\begin{tabular}{cc}
\hline $\mathrm{Chi}^{2}(1)$ & 0,04 \\
\hline Pro $>\mathrm{Chi}^{\mathbf{2}}$ & $\mathbf{0 , 8 4 4 0}$ \\
\hline
\end{tabular}

Sumber: Data diolah

Berdasarkan hasil uji Heteroskedastisitas di atas, nilai probabilitas chi ${ }^{2}$ sebesar 0,8440 $(>0,05)$ atau lebih dari 0,05 sehingga dapat diartikan uji ini tidak terkena heteroskedastisitas.

Tabel 3 Uji Chow

\begin{tabular}{cc}
\hline Effect Test & Prob. \\
\hline $\mathbf{F}(\mathbf{5}, \mathbf{3 5})$ & $\mathbf{8 , 4 9}$ \\
Prob $>\mathbf{F}$ & $\mathbf{0 , 0 0 0}$ \\
\hline
\end{tabular}

Sumber: Data diolah

Berdasarkan tabel di atas, nilai probabilitas $\mathrm{F}$ sebesar 0,000 atau kurang dari 0,05 sehingga pengujian berlanjut ke uji Hausman.

Tabel 4 Uji Hausman

\begin{tabular}{ll}
\hline $\mathrm{Ch}^{2}(5)$ & 0,11 \\
\hline Prob > chi $^{2}$ & 0,999 \\
\hline
\end{tabular}

Sumber: Data diolah

Berdasarkan tabel 4, nilai probabilitas $c h i^{2}$ sebesar 0,9998 atau lebih dari 0,05 sehingga model yang dipilih adalah random effect. 
Afrilita \& Wardani

Analisis Penanaman Modal Asing di Indonesia Tahun 2007-2016: Pendekatan Model Gravitasi

Tabel 5 Hasil Estimasi

\begin{tabular}{|c|c|c|c|}
\hline \multirow[t]{2}{*}{ Variabel Independen } & \multicolumn{3}{|l|}{ Model } \\
\hline & Common Effect & Fixed Effect & Random Effect \\
\hline Konstanta & $-94,496 *$ & $-86,042^{*}$ & $-96,496 *$ \\
\hline Standar Error & $(14,331)$ & $(21,909)$ & $(14,331)$ \\
\hline P-Value & 0,000 & 0,000 & 0,000 \\
\hline Log PDB per kapitaındo & $6,697^{*}$ & $7,151^{*}$ & $6,697^{*}$ \\
\hline Standar Error & $(2,087)$ & $(2,041)$ & $(2,087)$ \\
\hline P-Value & 0,003 & 0,001 & 0,001 \\
\hline Log PDB per kapitaınvs & $5,156^{*}$ & 3,753 & $5,156^{*}$ \\
\hline Standar Error & $(0,652)$ & $(2,726)$ & $(0,652)$ \\
\hline P-Value & 0,000 & 0,177 & 0,000 \\
\hline LogJarak & $-1,712^{*}$ & 0 & $-1,712^{*}$ \\
\hline Standar Error & $(0,348)$ & (omitted) & $(0,348)$ \\
\hline P-Value & 0,000 & - & 0,000 \\
\hline PTTK & $-0,003$ & $-0,019$ & $-0,003$ \\
\hline Standar Error & $(0,096)$ & $(0,079)$ & $(0,096)$ \\
\hline P-Value & 0,971 & 0,810 & 0,971 \\
\hline Indeks Politik Indo & $-0,790$ & $-0,812^{*}$ & $-0,790$ \\
\hline Standar Error & $(0,436)$ & $(0,357)$ & $(0,436)$ \\
\hline P-Value & 0,078 & 0,029 & 0,070 \\
\hline Keterbukaan Ekonomi & $0,064^{*}$ & $0,067^{*}$ & $0,064^{*}$ \\
\hline Standar Error & $(0,030)$ & $(0,026)$ & $(0,030)$ \\
\hline P-Value & 0,043 & 0,013 & 0,036 \\
\hline
\end{tabular}

Sumber: Hasil pengolahan data panel

Keterangan:*p<0,05

Dari hasil perhitungan model random effect, diketahui bahwa probabillitas nilai F-hitung sebesar 0,000. Dengan tingkat signifikansi 1\%, terdapat cukup bukti bahwa variabel independen yang terdiri dari PDB per kapita Indonesia, PDB per kapita negara investor, jarak Indonesia dengan negara investor, pendidikan terakhir tenaga kerja Indonesia, Indeks Stabilitas Politik Indonesia, dan keterbukaan ekonomi Indonesia secara bersamasama berbepengaruh terhadap variabel Penanaman Modal Asing di Indonesia.

Nilai $R$-Squared atau koefisien determinasi berguna untuk mengukur kemampuan model dalam menjelaskan variasi variabel dependen. Dari hasil analisis menggunakan random efect model, diperoleh $R$-Squared sebesar 0,7204 , yang artinya sebesar $72,04 \%$ variasi penanaman modal asing dapat dijelaskan oleh variasi pada variabel independen (PDB per kapita Indonesia, PDB per kapita negara investor, jarak Indonesia dengan negara investor, pendidikan terakhir tenaga kerja Indonesia, Indeks Stabilitas Politik Indonesia dan keterbukaan ekonomi Indonesia) sementara sisanya $27,96 \%$ dijelaskan oleh variasi lain di luar model.

Hasil regresi dalam penelitian ini menunjukan bahwa Produk Domestik Bruto per Kapita Indonesia berpengaruh positif terhadap PMA Indonesia pada derajat kepercayaan $1 \%$. $\mathrm{Hal}$ ini sesuai dengan hipotesis penelitian. Nilai koefisien PDB perkapita Indonesia sebesar 6,697 yang berarti apabila setiap kenaikan 1\% PDB perkapita Indonesia 


\section{Afrilita \& Wardani \\ Analisis Penanaman Modal Asing di Indonesia Tahun 2007-2016: Pendekatan Model Gravitasi}

sedangkan variabel lain tetap, maka PMA akan mengalami kenaikan secara rata - rata sebesar 6,697\%. Hal ini sejalan dengan penelitian Borrmann, Jungnickel, dan Keller (2005) bahwasanya PDB per kapita memiliki hubungan positif terhadap penanaman modal asing. Dimana PDB perkapita menjadi salah satu tolok ukur investor untuk menanamkan modalnya pada suatu negara (Borrmann dkk., 2005). Yaitu semakin tinggi PDB per kapita suatu negara, maka semakin banyak investo investasinya.

Hasil regresi dalam penelitian ini menunjukkan bahwa Produk Domestik Bruto per Kapita negara investor berpengaruh positif terhadap PMA Indonesia pada derajat kepercayaan 1\%. Hal ini sesuai dengan hipotesis penelitian. Nilai koefisien PDB perkapita negara investor sebesar 5,156 yang berarti apabila setiap kenaikan 1\% PDB perkapita Indonesia sedangkan variabel lain tetap, maka PMA akan mengalami kenaikan secara rata - rata sebesar 5,156\%. Hal ini dapat diimplikasikan bahwa tingginya PDB per kapita di negara investor menjadi salah satu kualitas dari negara tersebut dalam pertumbuhan perekonomian di Indonesia (Setyowati, Wuryaningsih, \& Kuswati 2008). Yang dimana semakin tinggi PDB per kapita negara investor maka akan semakin berani negara investor menanamkan modalnya ke negara luar.

Hasil regresi dalam penelitian ini menunjukan bahwa jarak negara investor memiliki hubungan negatif terhadap PMA Indonesia pada derajat kepercayaan $1 \%$. Hal ini sesuai dengan hipotesis penelitian. Nilai koefisien jarak antar negara sebesar $-1,712$ yang berarti apabila setiap kenaikan $1 \%$ jarak antar negara sedangkan variabel lain tetap, maka PMA akan mengalami penurunan secara rata-rata sebesar $1,712 \%$. Hal ini memberi arti bahwa faktor jarak sedemikian penting mengingat semakin dekat negara tuan rumah dengan negara investor, maka semakin besar kerjasama investasi yang dilakukan dan semakin mengurangi biaya transport yang dikeluarkan serta semakin jauh jaraknya maka akan semakin kecil kerjasama investasi yang dilakukan dan semakin banyak biaya yang dikeluarkan (Borrmann dkk, 2005).

Hasil regresi dalam penelitian ini menunjukan bahwa keterbukaan ekonomi Indonesia memiliki hubungan positif terhadap PMA Indonesia pada derajat kepercayaan $5 \%$. Hal ini sesuai dengan hipotesis penelitian. Nilai koefisien keterbukaan ekonomi Indonesia sebesar 0,064 yang berarti apabila setiap kenaikan 1\% keterbukaan ekonomi Indonesia sedangkan variabel lain tetap, maka PMA akan mengalami kenaikan secara rata - rata sebesar 6,4\%. Hasil penelitian ini sesuai dengan Hénin (2013) bahwa keterbukaan ekonomi mendorong suatu negara melakukan perdagangan internasional yang akan menyebabkan terjadinya perputaran uang dan peningkatan investasi. Ditambah lagi investor asing lebih tertarik dengan negara yang menerapkan sedikit hambatan atau lebih terbuka guna mempermudah kerjasama (Talamo, 2005). Yang dimana semakin terbukanya seuatu negara dengan kerjasama internasional maka akan semakin banyak atau mudahnya negara asing dan investor menanamkan modalnya di negara tersebut. Berbeda dengan variabel yang lainnya, Pendidikan terakhir tenaga kerja dan indeks stabilitas politik tidak memiliki pengaruh yang signifikan terhadap penanaman modal asing di Indonesia. 


\section{Kesimpulan}

Berdasarkan hasil penelitian mengenai Pendekatan Model Gravitasi Terhadap Penanaman Modal Asing Indonesia tahun 2007 - 2016, dapat diambil kesimpulan bahwa Produk Domestik Bruto (PDB), Variabel Produk Domestik Bruto (PDB) per Kapita negara investor, Keterbukaan Ekonomi berpengaruh terhadap peningkatan modal asing di Indonesia. sedangkan jarak antar Indonesia dengan negara investor berpengaruh negative terhadap penanaman modal asing. Pendidikan tenaga kerja serta indeks stabilitas politik muncul dengan hasil yang tidak diharapkan. Kedua variabel tersebut tidak memiliki pengaruh yang signifikan terhadap penanaman modal asing di Indonesia.

\section{Daftar Pustaka}

Borensztein, E., De Gregorio, J., \& Lee, J. W. (1998). How does foreign direct investment affect economic growth?. Journal of international Economics, 45(1), 115-135. Diakses dari https://olemiss.edu/courses/inst310/BorenszteinDeGLee98.pdf

Borrmann, C., Jungnickel, R., \& Keller, D. (2005). What gravity models can tell us about the position of German FDI in Central and Eastern Europe. HWW A Discussion Papers 328, Hamburg Institute of International Economics (HWW A).

Broadman, H. G., \& Recanatini, F. (2004). Where Has All the Foreign Investment Gone in Russia?. Forthcoming, Economics of Transition. https://doi.org/10.1596/1813-9450-2640

Buch, C. M., Kokta, R. M., \& Piazolo, D. (2003). Foreign direct investment in Europe: Is there redirection from the South to the East?. Journal of Comparative economics, 31(1), 94-109. Diakses dari https://ideas.repec.org/a/eee/jcecon/v31 y2003i1 p94-109.html

Frenkel M., Funke K., \& Stadtmann, G. (2004). A panel analysis of bilateral FDI flows to emerging economies. Economic Systems. 28(3), 281-300. Diakses dari https://ideas.repec.org/a/eee/ecosys/v28y2004i3p281-300.html

Hénin, P. Y. (2013). Macrodynamics: Fluctuations and Growth: A study of the economy in equilibrium and disequilibrium. London: Routledge.

Sarwedi. (2004). Investasi Asing Langsung di Indonesia dan Faktor yang Mempengaruhinya. Jurnal Akuntansi dan Keuangan, 4(1), 17-35. https://doi.org/10.9744/jak.4.1.pp.\%2017-35

Setyowati, E., Wuryaningsih, D. L., \& Kuswati, R. (2008). Kausalitas Investasi Asing Terhadap Pertumbuhan Ekonomi: Error Correction Model. Jumal Ekonomi \& Studi Pembangunan, 9(1), 69-88. Diakses dari https://journal.umy.ac.id/index.php/esp/article/view/1527

Shatz, H. J., \& Venables, A. (2000). The geography of international investment (Vol. 2338). World Bank Publications.

Svetlana, L., \& Mikael, L. (2006). Testing for foreign direct investment gravity model for Russian regions. University of Joensuu.

Talamo, G. M. C. (2007). Institutions, FDI, and the gravity model. In Workshop PRIN 2005 SU, Economic Growth; Institutional and Social Dynamics (25-27). Diakses dari http://citeseerx.ist.psu.edu/viewdoc/download?doi=10.1.1.472.9728\&rep=rep1\&ty $\mathrm{pe}=\mathrm{pdf}$

Widarjono., A. (2009). Ekonomi Pengantar dan Aplikasi. Yogyakarta: Penerbit Ekonisia. 